\title{
Linda Lappin
}

\section{Mapping the soul of place}

\begin{abstract}
This work describes some activities carried out by students in a creative travel writing class focusing on the soul of place conducted by the author for the University Study Abroad Consortium (USAC) study abroad program in Viterbo, Italy. After a brief discussion of the origins and evolution in meaning of the term' Genius Loci,' the soul of place is investigated as a link between place and identity as evinced in the works of various creative writers. Landscape narratives as discussed by Potteiger and Purinton and deep maps are applied as models for creative writing practice exploring the connections between the genius loci, pilgrimage, sacred space, sense of place, and personal identity within a unique Mediterranean context of story-places and storied places.

Keywords: genius loci, sense of place, landscape narratives, travel writing, University Study Abroad Consortium, USAC
\end{abstract}

In his poem, 'A Lost Tradition', the Irish poet, John Montague writes:

All around, shards of a lost tradition...

The whole landscape a manuscript

We had lost the skill to read

A part of our past disinherited (Montague 1972: 30)

In those lines, the search for an identity connected to the territory, traditions and language of Ireland is very specific, yet the imaginations of many writers today from all over the world will resonate to those words: 'The whole landscape is a manuscript we have lost the skill to read'. Montague's central trope, the metaphor equating landscape with text, invites us to turn our eyes upon the landscapes, real or imaginary, we inhabit, to interpret the signs scattered upon them and unravel the stories woven into them across time. This paper, describing some experiments with creative writing students focuses on the soul of place and suggests an approach to reading landscapes and to incorporating the impressions gained into creative writing activities.

The activities discussed here were conducted over a period of five years with students from the University Study Abroad Consortium, an American university study abroad program hosted at the University of Tuscia in Viterbo, Italy, enrolled in a semester-long literary travel writing workshop which I taught. These students were drawn from a wide range of US universities and colleges and hailed from diverse cultural and ethnic backgrounds. Although the majority of students came from humanities and social science programs and only a handful from the natural sciences, for many it was their first creative writing class, and in some cases, their first college-level literature class. The overall goal of the course was to investigate several major themes of literary travel writing (first impressions, illusion and disillusionment, displacement and dislocation, self-discovery, otherness, danger, sensuality, travel as initiation) with special emphasis on Italy, while guiding students to the completion of creative nonfiction /travel writing projects: detailed travel journals, memoirs, personal essays, and multimedia presentations celebrating their experiences in the Italian landscapes they had encountered.

In their research and writing activities for this class, students were to consider their relationship with the spaces, exterior and interior, with which they interacted and to explore the multitemporality of their new environment, using the intuitions and experiences they had as a stimulus for their creative work. With many Etruscan and Roman ruins located throughout the province of Viterbo (where it is not unusual to unearth an Etruscan tomb in 
your backyard), its intact medieval centres where the houses have been continually inhabited since the 1200s, Renaissance palaces and baroque labyrinth gardens stalked by surreal statues and decorated with alchemical emblems, strange wastelands wrought by Allied bombs, Tuscia (the name given to this corner of northern Lazio) offered many opportunities for 'time travelling'. These architectural markings were set within a stunning natural context: green rolling hills and rocky chasms, volcanic lakes, boiling sulfur springs, towering chestnut groves, all within a radius of ten miles of their university campus and easily accessible on foot, by bus, or car, providing a perfect palimpsest of story and storied-places to discover. An antiquated train connected the Viterbo train station to San Pietro Station in Rome thrusting students directly into the hub of a chaotic, multicultural, contemporary Italian city, with all its risks and enticements.

\section{The Genius Loci}

Our writing, reading and research were centered on the theme of the Genius Loci. In common, contemporary usage, when speaking of the Genius Loci, we are referring to the atmosphere or ambience of a place, or the qualities of its environment. In its older meaning deriving from ancient Roman culture, it signified the guardian spirit of a place. The Genius, a key concept in the religious thought of the ancient Romans, was an individual spark of divine nature dwelling in every person, place, thing, and activity. Individuals had their genii, as did categories of people (soldiers, senators, slave-holders, etc) as well as concrete and abstract things (wine, theatre, marriage, nursing) (Guirand 1973: 218). The genius of a human being (for females, the juno) was the creative force through which that person was engendered, appearing at birth and accompanying him or her till death. Often represented as a snake, universal symbol of time, cosmic energy, and renewal, the genius was a sort of 'abstract double' (Guirand 1973: 218) responsible for fostering the intellect, moral development, and health of an individual. In its tutelary function, it was assisted by numerous auxiliaries depending on a person's stage of life, status, and professional activity, and was associated with the household gods, the Penates and Lars, protectors of abundance and family life. The ancient Roman poet, Horace, defined the genius in Book II of his Epistles (14 BC) as the guardian spirit who controls the natal star or fate, and 'the god presiding over human nature' (Rudd 1989: 145). The Etruscans held a similar belief, as did the Greeks: the daemon.

The genii of places, called Genii Loci, spirits or souls of place, performed an analogous function for the places to which they were attached. They protected and governed a place, molded its landscape and character, determined its atmosphere, and influenced the vitality of all forms existing therein. Consequently, the Genii Loci also influenced the destinies of human beings living within their territory and the human endeavors unfolding there. Villages, towns, and buildings had their unique spirits, as did the different features of landscape: mountains, rivers, forests, springs, volcanoes. In his Reply to an Address of Symmachus written in 403 AD the fifth-century Roman Christian poet, Aurelius Prudentius Clemens, criticizes the pagan custom of attributing 'to gates, houses, public baths, taverns, each its own genius, and throughout every part of the city at every point ... thousands of geniuses, so that no corner shall be without its own ghost' (Prudentius 1953: 41). In the ancient Roman imagination, the environment swarmed with these hierarchically organized numen which hindered or helped the human beings with whom they interacted.

In order for communities and individuals to flourish in a given spot, it was necessary for them to harmonize their lives with the resident genius/genii. To this end, sacrifices were performed at special altars dedicated to the Genii Loci. Examples of such altars have been found throughout the Western Roman Empire, such as the one preserved today in the Corinium Museum in Cirenchester, UK. In the sculptural or pictorial iconography of these altars, the Genius Loci was often portrayed as a beautiful youth holding a libation vessel, or as a snake. In return for sacrifices received, the Genius Loci would protect and nurture its inhabitants and bless the activity the officiants wished to carry out within its jurisdiction: building a temple, planting a field, setting up a household, or establishing a fortification. Similar beliefs in guardian spirits of place have been recorded in such diverse cultures as Africa, Tibet, Australia, Japan, Polynesia, the American southwest. Bernard Anson, storyteller and researcher into the soul of place, writes in Carmen Via, a project inspired by the Australian songlines transposed to Italy: 
Genius loci means governing spirit of location. The implication is that in certain locations, human actions become trapped in certain patterns by a governing spirit. If you think the idea is zany, just watch out next time you visit an archaeological or monumental site in the ancient world. In the architecture you might detect locus patterns conducive to loving and nurturing, or to fighting and pillaging, locus patterns of law-making or of law-breaking. Often you will discover infernal worship or supernal worship - sometimes both together on the same site... It is in the realm of the intangible that the gravity of genius loci operates best simply because that is its natural element. How often you see a Christian church built upon the exact same site of a pagan temple. Thousands of years of diverse associations with the supernatural, all conducted on the same spot... Any prospectus for this type of real estate should tell you what kind of genius loci comes into the deal because sooner or later, if you live and work in these parts, you will be required to make executive decisions about issues which are governed by it. (Anson 2006: 16)

The concept of the Genius Loci entered English literature in the eighteenth century, when writers, such as Alexander Pope, under the influence of the classics, increasingly turned their interest to the bucolic and pastoral, to rural, sublime, and picturesque landscapes, and also to gardens, in which human intervention equaled that of nature as a shaping force. Later adopted by architecture and urban planners, the term Genius Loci came to mean 'the sense people have of a place, understood as the sum of all physical as well as symbolic values in nature and the human environment' (Jiven \& Larkham 2003: 70), conditioned both by culture and history and reflecting 'the work and aspirations of the society at present in occupancy but also that of its precursors in the area' (Conzen cited in Jiven \& Larkham 2003: 69).

Contemporary practitioners in these fields recognize that beneath the historical and cultural stratifications in a landscape, 'certain localities have an attraction which gives us a certain indefinable sense of well-being and which we want to return to, time and again' (Jackson 1994: 157-158). That elusive source of attraction capable of generating well-being is none other than the Genius Loci in its original meaning: a nurturing (or withering) force in the landscape.

\section{Place, non-places, identity, Genius Loci}

The historical-cultural process through which places acquire identity and significance for an individual or a community springs from a series of essential interrogations concerning self and place: What is this place? What determines its particular atmosphere and texture? What has happened here in the past? How have past events here impacted the present? Who am I in this place? What is my/my community's connection to it? Do I/we belong here?

For Simone Weil, 'To be rooted is perhaps the most important and least recognized need of the human soul' (Weil 2001: 43). Yet French anthropologist, Marc Augé, suggests that citydwellers are no longer individuals possessing roots but rather a flux of humanity transiting urban spaces - from hospitals and housing blocks to subways and shopping malls, necessitating a new kind of social space which facilitates movement: non-places 'formed in relation to certain ends (transport, transit, commerce, and leisure)' (Augé 1995: 94). Over time, non- places may break down into what Rem Koolhaas terms junkspace, the residue left after 'modernization has run its course' (Koolhaas 2002: 175), as is painfully evident in the contemporary cityscapes of Detroit or Athens. Amid these anonymous or decaying spaces, as theologian Douglas Burton-Christie so eloquently laments, we have lost our sense of place, our ability to 'become intimate with a landscape,' and 'to enter into and be shaped by the stories and culture of a place' (Burton-Christie 1999: 59).

Yet despite the proliferation of non-places in our lives, the psyche remains haunted by its connections to place through family and community history. In a recent essay in the London Review of Books, Richard Lloyd Parry writes of the ghost emergency that has burgeoned throughout northern Japan following the tsunami which swept away towns and villages never to be rebuilt, drowning thousands of humans and animals, washing away cemeteries and other sacred places where the spiritual heritage of the community had been preserved for generations. Parry informs us that Shinto, Buddhist, and Christian priests have been working overtime to stem an invasion of hungry spirits swarming across the territory, threatening 
mental health and public order. In addition to psychiatric and religious intervention to address the collective trauma, story-telling centres have been created where survivors are encouraged to work through their grief and guilt by recounting stories of the supernatural phenomena, like ghostly sightings or acts of spirit possession, to which they have fallen victim (Parry 2014: 13-17). The narratives sedimented in a landscape may not necessarily be happy ones, but knowing and telling them may keep us sane, and heal damage incurred when the bonds between identity and place are abruptly severed by personal or collective tragedy.

In English literature, the Genius Loci has sometimes been seen as the link between identity and place. One modernist writer particularly sensitive to the psychological influences of the Genius Loci was DH Lawrence who tried to explain it in terms of geology, astronomy, chemistry, and climate: 'Different places on the face of the earth have different vital effluence,' he wrote in his essay, The Spirit of Place, 'different vibration, different chemical exhalation, different polarity with different stars: call it what you like, but the spirit of place is a great reality' (Lawrence 2003: 170). He also believed that human populations were attracted to a territory by means of a mysterious affinity with it:

We cannot see that invisible great winds carry us unwitting, as they carry locust storms, and direct us before our knowledge as they direct migrating birds. A place attracts its own human element and the race drifts inevitably to its own psychic geographical pole. (Lawrence 2003: 170)

Moreover, Lawrence claimed, 'All art partakes of the Spirit of Place in which it is produced' (167). His own work may be read as a journey from one inner and outer location to another (Clark 1980) - England, Italy, Australia, Mexico, New Mexico in search of a place whose spirit was attuned to his own. Each of his great novels and literary travel books recreates a particular environment, emphasizing the unique bond between identity and place and the devastation that arises when that bond is broken, contaminated, or exploited for economic gain as is evident in both Lady Chatterley's Lover and Sketches of Etruscan Places.

Lawrence Durrell, a postmodernist who continued Lawrence's investigations into the Genius Loci and its role in literature, made an even bolder claim: 'the important determinant of any culture is after all the spirit of place' (Durrell 1969: 56). 'Man is only an extension of the spirit of place' (Durrell 1982: 158) says Nessim in Justine, Book I of The Alexandria Quartet, Durrell's masterpiece in which the author adopted a new narrative method 'stereoscopically' (Andrewski \& Mitchell 1959) recounting the same series of events from different points of view so that the truth of what happened and why changes according to the narrator's placement in space and time. Durrell's novel is built into the real topography and geography of Alexandria: 'from the handsome Rue Fuad to the meshed Arab backstreets ... the hashish cafes of the slums or the sandy approaches of the Western Desert ... stifling attic bedrooms, brothels, and pleasure pavilions. Most of this is factual' (Morris 2012). The many characters and narrators of the Quartet find themselves 'entrapped' by the Genii Loci of the city which used them 'as its flora - precipitated in us conflicts which were hers and which we mistook for our own ...' (Durrell 1982: 29). Darley, the main narrator of Justine, elucidates: 'We are the children of our landscape; it dictates behavior and thought in the measure we are responsive to it' (1982: 3).

Darley here is voicing Durrell's own views as set forth in his essay 'Landscape and Character' in which he asserts that all great novels are rooted in and attuned to a specific locale. 'You cannot transplant them without totally damaging their ambience and mood; any more than you could transplant Typee' (Durrell 1969: 156). For Durrell, character is a function of landscape; individuals are molded by the places they live. The goal of the travel writer or novelist is 'to isolate the germ of the people expressed in its landscape' (158). This may be achieved by entering into silent communion with the landscape, an act which he termed quiet identification. 'All landscapes ask the same question in the same whisper: I am watching you - are you watching yourself in me?' (158).

Musing on the Greek landscape while in exile in Egypt during the Second World War, he wrote, 'Walking in those valleys, you knew with complete certainty that the traveler in this land could not record. It was rather as if he himself were recorded ... Nowhere else has there ever been a landscape so aware of itself" (Durrell 1962: 131). In such places, for Durrell, the writer is both a player in the landscape and a mirror for its own awareness of itself, an awareness originating in the Genius Loci. Ralph Waldo Emerson also reported a similar 
experience of being 'watched' by the landscape. 'I am not alone and unacknowledged', he claimed, speaking of fields and woods, 'They nod to me and I to them' (Emerson 1971: 10).

The contemporary American nature writer, Greta Erhlich, would agree with Durrell's 'quiet identification': 'To see and know a place is a contemplative act. It means emptying our minds and letting what is there in all its multiplicity and endless variety come in' (Erhlich 1987: 17). But what comes in for Erhlich is the returning projection of our own mind: the landscape is a 'spectacle' representing 'our frame of mind, what we know and what we seek to know' (17). In conclusion, we may say that the Genius Loci has often been understood as a form of consciousness, indwelling or refracted, operating within landscape and architecture. As consciousness, then, it has stories to tell.

The first goal of our writing class, taking a hint from Lawrence Durrell, was to investigate our responses to places, to understand what is meant by the term 'the sense of place' and seek deeper for the Genius Loci. In our attempt to isolate the germ expressed in the landscape and people of Tuscia, we sought diverse ways to tune in to the stories of the Genius Loci and learn how our own stories entwined with them. At such pulse points we intersected 'a history, a long existence, offering it our fresh discovery as a regeneration' (Hazzard 1983).

\section{Story places and storied places}

'We come to know a place because we know its stories'

(Potteiger \& Purinton 1998: 5)

The first place we looked for those stories was in the landscape narratives of Tuscia. This term has been defined as the interplay of landscape and narrative. Narratives 'intersect with sites, accumulate as layers of history, organize sequences and inhere in the materials and processes of the landscape' (Potteiger \& Purinton 1998: 5). In any given landscape, the narratives of history, religion, myth, folklore, art, oral tradition, community identity, politics, gossip, are all inscribed in tangible features: from mountains, rivers, and roads to buildings, ruins, billboards, graffiti, artifacts. Given the compressed multitemporal texture of the Italian setting, there were many such narratives in Tuscia to explore. There where the past dwells within the spaces of the present, Jean Starobinski postulates a bass line upon which rests a polyphony of 'actions, thoughts and reminiscences, chiming the hours of the terrestrial day and marking the position that used to be (and could still be) occupied there by ancient ritual' (Starobinsky cited in Augé 1995: 75). Marc Augé comments, 'the expression Starobinski employs to evoke ancient places and rhythms is significant. Modernity does not obliterate them but pushes them into the background. They are like gauges indicating the passage and continuation of time' (Augé 1995: 77). Starobinski's bass line may also be viewed as an offshoot the Genius Loci, a deeply engrained melodic strain or series of pulses, like a heart beat; an archetypal narrative embedded in history and topography, a great tap root to which all other narratives are attached by tendrils.

In our literary travel writing class, we asked ourselves where to look for the 'bass line' narrative of Tuscia. By what means do narratives become attached to places? How do we navigate such a stratified and sedimented terrain? How could we, as outsiders to the community, unfamiliar with its stories and its interpretive framework, with its codes, references, registers, and with the appropriate use of its stories, dig out and interpret the narratives we found there ? How could we sort out the many strands: historical, religious, political, mythical, archaic, ideological, contemporary entangled in every square inch of its space, in every cobblestone and antique door knocker? Whose stories were being told and to whom? For what purpose? How and where did our personal narratives through which we were shaping our own experience of Tuscia intersect others to make a new intertextual layer? In what larger narratives were we actors? We began by examining the types of landscape narratives found in our environment. In Landscape Narratives, Potteiger and Purinton identify nine types (Potteiger \& Purinton 1998: 11) charted below:

\begin{tabular}{|l|l||}
\hline $\begin{array}{l}\text { 1. Narrative } \\
\text { Experiences }\end{array}$ & $\begin{array}{l}\text { Routines, rituals, events following narrative structures: festivals, } \\
\text { processions, pilgrimages, daily journeys, crossing the threshold }\end{array}$ \\
\hline $\begin{array}{l}\text { 2. Associations } \\
\text { and References }\end{array}$ & $\begin{array}{l}\text { Elements in landscape connected with experience, event, history, } \\
\text { religious allegory, or other forms of narrative }\end{array}$ \\
\hline \hline &
\end{tabular}




\begin{tabular}{||l|l||}
$\begin{array}{l}\text { 3. Memory } \\
\text { Landscapes }\end{array}$ & $\begin{array}{l}\text { Places serving as the tangible locus of memory both public and personal: } \\
\text { monuments, museums, preserved buildings }\end{array}$ \\
\hline $\begin{array}{l}\text { 4. Narrative } \\
\text { Setting and } \\
\text { Topos }\end{array}$ & $\begin{array}{l}\text { A highly conventionalized setting linked with particular events evoked } \\
\text { repeatedly in a culture's narratives }\end{array}$ \\
\hline \hline $\begin{array}{l}\text { 5. Processes } \\
\text { festions or events caused by some agency. Erosion, growth, succession, }\end{array}$ \\
\hline $\begin{array}{l}\text { 6. Interpretive } \\
\text { Landscapes }\end{array}$ & Elements and programs that tell what happened in a place \\
\hline $\begin{array}{l}\text { 7. Narrative as } \\
\text { Form Generation }\end{array}$ & Using stories to give order \\
\hline $\begin{array}{l}\text { 8. Story-telling } \\
\text { Landscapes }\end{array}$ & Gardens, memorials, themed landscapes designed to tell specific stories \\
\hline $\begin{array}{l}\text { 9. Genres of } \\
\text { Landscape } \\
\text { narratives }\end{array}$ & $\begin{array}{l}\text { Places shaped by culturally defined narrative forms or genres, like } \\
\text { legend, epic, biography, myth }\end{array}$ \\
\hline \hline
\end{tabular}

Figure 1. Landscape Narrative Types adapted from Potteiger \& Purinton, 1998

\section{Walking the Route}

'Walking is like a story, a series of events for which the land acts as a mnemonic'

(Pearson \& Shanks 2006)

'A road establishes a sequence while opening the possibilities of chance encounters'

(Potteiger \& Purinton 1998)

Of the many landscape narrative subtypes listed in the above chart under the first category, there was one in particular to which students responded with exceptional enthusiasm, that of pilgrimage interpreted broadly: religious, spiritual, family, secular, private, artistic, experienced as a consolidation of identity and a rite of passage. For some, their pilgrimage entailed a visit to remote villages in Southern Italy from where ancestors had emigrated to the USA in the nineteenth century; for others, a trip to Auschwitz as an act of witnessing that such horrendous places did once exist. Many found inspiration in Tuscia's historically important role as the last stop on the old pilgrim's route, the Via Francigena, before reaching the gates of Rome [2]. Overlaying an ancient Roman highway which in turn had been grafted upon Etruscan trails, the Via Francigena provided a very concrete, topographical manifestation of Starobinski's bass line with its 'infinite interlacing of destines', indicating the 'continuation of time.'

The Via Francigena ran from Calais to Reims, Losanne, through the Mont Genèvre Pass and down the middle of the Italian boot. Upon entering Tuscany, it passed through Siena, then rambled southwards into Tuscia, around Lake Bolsena, through Viterbo, and down to Rome. Every town and hamlet along the way, and along its many detours, is graced by churches, fountains, convents, towers, and monuments which once served as rest stops, hospitals, hospices, toll booths, to meet the needs of the thousands of people who traveled down that route, popularized by Charlemagne in the ninth century and first mapped by the Sigeric the Serious, archbishop of Canterbury, in the tenth century. Unlike the Roman archetype of a wide, well-paved road suitable for vehicular traffic, the Francigena was really more a network of trails through woods and fields, skirting sublime landscapes.

Although the Via Francigena was designated a major cultural route in 2004 by the Council of Europe, it cannot be compared to that of the St James Way in Spain, promoted by religious mass tourism, frequented by thousands of walkers every year, equipped with hostels and taverns, and celebrated in globally bestselling memoirs and fiction. The neglected Francigena unwinds through isolated farmland, disappears into backwoods and peters out beneath long stretches of modern highway with no safe place for pedestrians but nettle-filled ditches at the roadside. There are few places to sleep but abandoned farmhouses or an occasional monastery. Roaming sheepdog, hunters, vagrants, wild boars, deadly vipers may easily be encountered round the next curve. A hike along this route guarantees true solitude, 
opportunities for epiphany in nature, and the satisfying challenge of potential risk. By slipping on a pilgrim's shoes, students assumed the archetypal identity of the wayfarer and became themselves protagonists not only of a compelling local landscape narrative, but of one of the most ancient and well-loved patterns in the history of story-telling: that of quest. Whatever their goal, they were 'walking' an intimate story of their own making while participating in an overarching narrative which had shaped the landscape and identity of the area for centuries. One student wrote:

To be a pilgrim means to walk away from comfort, to seek the unseen, to embrace your purpose, and most importantly, to take time to listen to the voice of your own heart. On a pilgrimage you have time to reflect on the meaning of every step you take, on how the roads you have traveled have created who you are.

Drinking from the same fountains where those pilgrims once drank, resting in the same places, I meditated on how people from all walks of life have come together on this narrow gravel road, weaving through the Italian countryside. That day, my expectations were exceeded as I walked my way towards the altar and peered at the imprints of Saint Christina's feet. My heart was not prepared for the plunge it took, or for the inspiration it found in a saint so young in whose footprints I have found a new direction. [1]

The experience described above evokes the participation in nonlinear time which Mircea Eliade postulates as essential to the experience of sacred space, when the individual may feel connected to all previous and future generations, or feel a strong identification with a cosmic ancestor (Eliade 1959: 45). For this student, a saint's footprints impressed in stone on the altar of a medieval church represented a powerful metaphor for the spiritually transformative experience of 'walking the route' in an act of pilgrimage, linking her experience to that of countless others, all the way back to Saint Christina herself, martyred in Ancient Rome. Such experiences of hypertime or the expanded awareness of self in time/space, argues Tony Hiss in his study In Motion, are the core experience of 'Deep Travel' (Hiss 2010: 55), an epiphany of dislocation and temporal discontinuity when we are torn from habit and posed in a new rapport to our environment. At such moments, old perceptual habits like old selves are sloughed off and the wonder of the world refreshes our senses as in childhood. For Hiss, through 'Deep Travel', even the most mundane places may become numinous and acquire intimate personal meanings .Mircea Eliade suggests that such experiences even when lacking an apparent religious foundation are bound up with our sense of the sacred (Hiss 1959: 45).

\section{Sacred spaces/sacred places}

For Eliade, non-traditional societies perceive space as neutrally uniform and undifferentiated, while traditional ones differentiate between sacred and profane space (Eliade 1959: 45). The former is regenerative, empowering, eternal, providing a link to cosmic events. Yet even in our non- traditional Western society, remarks Larry E Shiner, we 'are not in space as shoes are in a box' (Shiner 1972: 424). We interact with our space, we imbue it with meaning. We breathe in its air, so that part of it becomes part of ourselves. Eliade notes how we may experience some places as possessing special qualities due to our personal associations with them, such as our birthplace, or places where we felt strong emotions, like falling in love, and affirms that this is a degenerated form of religious experience. In these 'holy' places of our personal universe, an individual may receive 'a revelation of the reality other than that in which he participates in his daily life' (Eliade 1959: 24).

While walking the landscape narrative of pilgrimage along the Via Francigena, students discovered that their own personal stories and revelations were inscribed in a palimpsest of storied places in which the narratives were firmly rooted in a series of traditional sacred spaces syncretically stratified across the centuries from prehistory to the present. Like the landscape of Greece, where Patrick Leigh Fermor once noted, 'there is hardly a rock or a stream without a battle or a myth, a miracle or a peasant superstition; talk and incident, nearly all of it odd or memorable, thickens round the traveler's path' (Fermor 1957: 7), a polyphony of voices was heard at every turning of the Francigena trail. At each step, other landscape narrative types listed in Potteiger and Purinton's chart meshed with the one we were pursuing, especially pertaining to the second and third categories : 'associations and 
references' connected to myth, history, and religion, and 'memory landscapes'. Scattered like shards in the landscape were every type of sacred place/monument imaginable, as listed in Martin Grey's catalogue of sacred place typologies in his study Sacred Earth, from sacred mountains and bodies of water, pyramids, oracular caves, saints' birthplaces, female and male deity sites, labyrinth sites (Grey 2007: 11). Each one of these topographical features may be the receptacle of the Genius Loci.

The act of walking allowed us the privileged position and pace to acquaint ourselves with these signs in the landscape. Then came the task of gathering and interpreting, those 'lost skills', evoked in John Montague's poem quoted at the beginning of this essay, which would help us read the landscape and situate ourselves and our stories within it. For this we sought help in the construct of the 'deep map' popularized by William Least Heat-Moon in his seminal work PrairyErth: A Deep Map.

\section{The deep map}

The term 'deep map' is now regularly employed by geographers, sociologists, environmentalists, ecologists, and site-specific performance artists to signify an intensive exploration of a given geographical spot. Michael Pearsons and Michael Shanks provide this definition in Theatre: Archaeology:

Reflecting eighteenth-century antiquarian approaches to place which included history, folklore, natural history and hearsay, the deep map attempts to record and represent the grain and patina of place through juxtapositions and interpenetrations of the historical and the contemporary, the political and the poetic, the factual and the fictional, the discursive and the sensual. (Pearsons \& Shanks 2006: 64)

A deep map, then, is a sample swatch of the multiple manifestations of the Genius Loci. The term itself seems to have been coined by Heat-Moon, who after publishing his very successful 'horizontal' travel book, Blue Highways - a restless, rootless ramble across America - decided to take a 'vertical trip' for his new project, heeding a suggestion of $\mathrm{N}$ Scott Momaday in The Way to Rainy Mountain:

Once in his life a man ought to concentrate his mind upon the remembered earth. He ought to give himself up to a particular landscape in his experience, to look at it from as many angles as he can, to wonder about it, to dwell upon it. (Momaday 1969: 83)

In PrairyErth, Heat-Moon's remembered earth is a very circumscribed piece of grassland set dead centre of the continental USA: Roniger Hill, from which radiates a territory of 778 square miles known as Chase County, a lonely place of transit successively abandoned by tribal peoples, settlers, speculators, and modern residents. To create his 'topographic map of words' (Heat-Moon 1991: 15) the author began by first obtaining 'twenty-five U.S.

Geological Survey maps that cover Chase County to the measure of an inch and a half to the mile, maps so detailed that barns and houses and windmills appear' (15) which he laid out on his living room floor and studied by walking across them. 'As I traipsed around this paper land, a shape came to me; [it] formed a sort of grid such as an archaeologist lays over the ground he will excavate. Wasn't I a kind of digger of shards?' (15). He then proceeded to test the grid against the territory, hiking across Chase County section by section 'in quest of the land and what informs it', (10) challenging the actual form of the grid itself, with its prisonlike grille of ninety-degree angles designed to 'subdue wildness' to lead him into the 'dark loomings' (15) of his own connection to the land.

After eight years of research and six years of writing, his end product is a vertical descent through recent and remote history down into geological time. PrairyErth weaves together the discourses of natural history, local history and folklore, oral testimony by local residents and scientific studies; autobiography, sociology, anthropology, archaeology, ecology. Ultimately, he discovers while stumbling on in a half somnolent state like a 'sea bottom walker in a bed of kelp' (Heat-Moon 1991: 104) that his real bond to the land lies deep beneath the surface, perceptible only to the non rational mind. 'Facts carry a traveler only so far. At last he must penetrate the land by a different means for to know a place in any real or lasting way is to 
dream it. That is how we come to belong to it in the deepest sense' (105). Heat-Moon's evocation of dreaming as a way of knowing a place and belonging to it is borne out in Richard Lloyd Parry's findings regarding Japanese tsunami survivors whose deep ties to their vanished towns and villages surfaced in nightmares, psychotic episodes, and collective hallucinations in which desecration/loss of sacred places and impossibility of a proper burial in a sacred place for countless victims were the source of deep communal anguish (Parry 2014: 13-17).

The deep map configures narratives. It is a matrix of intertextual story-telling, charting our movements through the landscape or cityscape, tracing the pathways of our habits and rituals, depositing our experiences over time in its folds, intersecting at every turn the mesh of lives and stories that have preceded us. It is a tool for vertical 'dwelling' in 'relational, historical' places. In adapting deep mapping methods as writing prompts for our writing class, students were asked to make a deep map of a spot they could observe and explore intensively throughout the course of a semester, paying attention to any forms of narrative they found operating there. First they were asked to determine the precise boundaries of the place to explore, then sketch a rudimentary map of it on which to annotate their experiences using any system they liked: stick figures, post-its, collage, photographs, or handwritten notes, indicating changing itineraries, encounters, and landmarks of personal significance or other features or information. Observation and writing exercises in situ were complimented by research using formal documentation, informal sources (legends, hearsay) and interviews. In addition to sections of the Via Francigena, other places mapped included urban ones [3] such as cafes, squares, markets, subways, ruins and abandoned buildings, street corners, bus stops, train stations. After every exploration of the space, they updated their maps to add new material. They then drew ideas from the map to write an essay.

As our attention became more focalized on specific aspects or areas of our maps, we tried to single out objects or specific sense impressions which in some ways encapsulated like a talisman or synecdoche our entire experience related to a place charted on our deep map. For the student whose paper is quoted above, it was a medieval relic of a saint's footprints impressed in stone, for another it was the carcass of a motorino chained to a lamppost, successively denuded of its recyclable parts over the weeks, while to another it was the joyous explosion of espresso coffee bubbling up in her coffee pot every morning. That talisman, charged with the power of place embodied our individual contact with the Genius Loci. From there, we explored the way stories are encoded in the objects that make up our physical environment and experimented with writing prompts based on objects of everyday use, inspired by the writings of Pablo Neruda, Francis Ponge, and Gaston Bachelard.

\section{Conclusion}

For Marc Augé, the sameness of the supermodern landscape is shaped by the homogenization of globalized consumption - the industrial areas, fast food joints, and shopping centers all over the world are tediously identical in appearance and contents. It's in those few forlorn corners, like Tuscia, where homogenization has not been entirely successful that the distinctive features of placeness manifest and the Genius Loci springs up through the cracks. To find it, we need only deviate from the main road, stop the car, get out, and walk. If as Augé intimates, we surrender our individuality to an algorithm as we are jostled along through non-places, we might regain a bit of what we have lost by setting our feet down on the soil of a real 'relational, historical' 'place'. Walking through a place then becomes not only a method of story-making, but an affirmation of the self, a challenge to corporate control, a method of personal appropriation of landscape. There is nothing new in this, inveterate walkers from William Wordsworth to Charles Baudelaire, Walter Benjamin and the Situationists have extolled the social and political significance of footloose perlustration of both rural and urban territories. Walking through the landscape is above all an act of pilgrimage, if we examine the origins of the word pilgrim: from 'per agros' or 'through fields', meaning 'outside the city', evoking a stranger, wanderer, or outsider who has temporarily detached himself or herself from the rhythms and rituals of urban society, intent on an entirely personal goal.

Through performing the landscape narrative of pilgrimage and working with deep maps, students not only familiarized themselves with the topography and history of an area, but came to understand that their personal experiences while exploring it reflected larger issues 
found in travel writing and the psychology of place. They experienced how the imagination can 'make a pattern, compose a story' (Lopez 1997: 25) out of shards gathered in the landscape and came to see how the stories of the place were enmeshed with the stories of their own making. They initiated a conversation with the Genius Loci and discovered as Barry Lopez suggests, that through 'our own storied relationship to a place, a place comes to occupy us just as we occupy it' (Lopez 1997: 25).

The early twentieth-century English writer, Mary Butts, believed that it is possible to' become imaginatively conscious' of the places we love, for which we create personal maps in our minds:

These maps are individual to each lover of a city, charts of his translation of its final significance, of the secret working of men's spirits which through the centuries have saturated certain quarters, giving them not only character and physical exterior, but quality, like a thing breathed. Paris is propitious for the making of such magic maps. (Butts 1992: 237)

Butts believed that the Genius Loci is created through the accumulation of human lives in a place over centuries. Vernon Lee, a contemporary of Butts, once hinted that when we leave a place, some of our energy remains behind to mingle with the spirit of place. I have no way of knowing if that was true for the students in this class. My one wish for them was to return home with well-written, multi-textured journals and essays testifying to their imaginative awareness of a place, Tuscia, which like Butts' Paris is propitious for the making of magic maps.

\section{Notes}

[1] From a class essay by USAC travel writing student Tamra Duvall, used with permission from the student. return to text

[2] See Mary Jane Cryan's recreation of Cardinal Henry Stuart, Duke of York's journeys along this route in the eighteenth century in her study Travels in Tuscany \& Northern Lazio (Etruria Editions 2004). return to text

[3] George Perec's An Attempt at Exhausting a Place in Paris (1975) provided an interesting model for imitation. return to text

\section{Works cited}

Andrewski, G \& J Mitchell 1959 'Interview with Lawrence Durrell', Paris Review 22: http://www.theparisreview.org/interviews/4720/the-art-of-fiction-no-23-lawrence-durrell (accessed 14 April 2014) return to text

Anson, B 2006 Carmen Via, Semar Publishers, Le Hague return to text

Augé, M 1995 Non-Lieux, trans J Howe, Verso, New York return to text

Burton-Christie, D 1999 ‘A Sense of Place’, The Way 39 (January): 59-72 return to text

Butts, M 1992, From Altar to Chimney Piece, McPherson, Kingston, New York return to text

Clark, LD 1980 The Minoan Distance: The Symbolism of Travel in D.H. Lawrence, University of Arizona Press, Tucson AZ return to text

Durrell, L 1962 Prospero’s Cell, Faber, London return to text

Durrell, L 1969 'Landscape and Character', in The Spirit of Place: Letters and Essays on travel, Faber, London: 156-163 return to text

Durrell, L 1982 The Alexandria Quartet, Justine, Faber \& Faber, London return to text

Eliade, M 1959 The Sacred and the Profane, Harcourt Brace, New York return to text

Emerson, RW 1971 'Nature', in Collected Works, Harvard University Press, Cambridge MA: 8-49 return to text

Erhlich, G 1987 The Legacy of Light, Knopf, New York return to text 
Fermor, PL 1957 Mani, Murray, London return to text

Grey, M 2007 Sacred Earth, Sterling, New York return to text

Guirand, F (ed) 1973 New Larousse Encyclopedia of Mythology, trans R Aldington \& D Ames, Prometheus Press, New York return to text

Hazzard, S 1983 'Points of Departure', New York Times (March 13):

http://www.nytimes.com/1983/03/13/travel/points-of-departure-by-shirley-hazzard.html (accessed 19 April 2014) return to text

Heat-Moon, WL 1991 PrairyErth: A Deep Map, Houghton Mifflin, New York return to text

Hiss, T 2010 In Motion, Knopf, New York return to text

Jackson, JB 1994 A Sense of Place, a Sense of Time, Yale University Press, New Haven CT return to text

Jiven, G \& P Larkham 2003 'Sense of Place, Authenticity, and Character', Journal of Urban Design 8, 1: 67-81 return to text

Koolhaas, R 2002, 'Junkspace', October 100 (Spring): 175-190 return to text

Lawrence, DH 2003 'The Spirit of Place', Studies in Classic American Literature Vol 2, Cambridge University Press, Cambridge: $167-179$ return to text

Lopez, B 1997 'The Literature of Place', Portland Magazine (Summer): 22-5 return to text

Momaday, NS 1969 The Way to Rainy Mountain, University of New Mexico Press, Santa Fe NM return to text

Montague, J 1972 The Rough Field, Dolmen Press, Dublin return to text

Morris, J 2012 'Rereading the Alexandria Quartet', The Guardian (24 February):

http://www.theguardian.com/books/2012/feb/24/alexandria-quartet-lawrence-durrell-rereading (accessed 10 April 2014) return to text

Parry, RL 2014 'Ghosts of the Tsunami', London Review of Books 36, 3: 13-17 return to text

Pearsons, M \& M Shanks 2006 Theatre: Archaeology, Routledge, London return to text

Perec, G 2010 [1975] An Attempt at Exhausting a Place in Paris, trans M Lowenthal, Wakefield Press, Cambridge MA return to text

Potteiger, M \& J Purinton 1998 Landscape Narratives: Design Practices for Telling Stories, Wiley \& Sons, New York return to text

Prudentius Clemens, A 1953 [b348] 'A Reply to an Address of Symmachus Book 2', Prudentius Book II, trans HJ Thomson, Loeb Classical Library, Harvard University Press, Cambridge MA return to text

Rudd, N (ed) 1989 Horace: Epistles Book II and Ars Poetica, Vol 2, Cambridge University Press, Cambridge return to text

Shiner, LE 1972 'Sacred Space, Profane Space, Human Space', Journal of the American Academy of Religion 40, 4: 425-436 return to text

Weil, S 2001 The Need for Roots, Routledge Classics, New York return to text

A novelist, poet, and travel writer, Linda Lappin holds an MFA from the University of Iowa Writers Workshop. She is the author of The Etruscan (Wynkin deWorde, 2004), Katherine's Wish, a novel dealing with the life of Katherine Mansfield (Wordcraft, 2008), Signatures in Stone: A Bomarzo Mystery (Pleasure Boat Studio, 2013) and of many critical and biographical essays concerning the work of women artists and writers of the 1920s. Much of her own creative work draws inspiration from the landscape narratives of the Mediterranean. Some of the material discussed in the present article is drawn from her forthcoming creative writing book, Genius Loci: A Writer's Guide to Conjuring the Soul of Place. She is a lecturer in English at the Sapienza University of Rome. www.lindalappin.net 
TEXT

Vol 18 No 1 April 2014

http://www.textjournal.com.au

General Editor: Nigel Krauth. Editors: Kevin Brophy \& Enza Gandolfo text@textjournal.com.au 